\title{
Metal-organic Framework [H2NMe2]3 [Tb(PDA)3] Induces Cytotoxic Effects and Changes DNA Methylation-related Gene Expression in a Human Fibroblast Cell Line
}

\section{Leydi Maribel Carrillo-Cocom}

Universidad Autónoma de Yucatán: Universidad Autonoma de Yucatan

\section{Lucia Juárez-Méndez}

Universidad Autónoma de Yucatán: Universidad Autonoma de Yucatan

\section{Susana Rincón}

Tecnológico Nacional de México: Tecnologico Nacional de Mexico José María Rivera-Villanueva

Universidad Veracruzana

\section{Geovanny Nic-Can}

CONACyT Campus de Ciencias Exactas Facultad de Ingeniería Química

Alejandro Zepeda ( $\square$ alejandro.zepeda@correo.uady.mx )

Universidad Autonoma de Yucatan https://orcid.org/0000-0002-0587-5039

\section{Research Article}

Keywords: cytotoxic, DNA methylation, human cells, metal organic framework

Posted Date: April 26th, 2021

DOI: https://doi.org/10.21203/rs.3.rs-396673/v1

License: (c) (1) This work is licensed under a Creative Commons Attribution 4.0 International License.

Read Full License 


\section{Abstract}

In this work, we describe the effect of six concentrations $(0.05,0.1,0.2,0.4,0.8$ and $1.6 \mathrm{mg} / \mathrm{mL})$ of a metal-organic framework [H2NMe2]3 [Tb(PDA)3] on the viability of human fibroblast cells (hFB) after 48 $\mathrm{h}$ of exposure. The terbium metal-organic framework may be utilized for a variety of environmental and human health applications due to its luminescent properties and high thermal and water stability. However, the cytotoxic and epigenetic effects of lanthanide MOFs have not been fully elucidated to date. Therefore, we evaluated the cytotoxic effects, internalization and changes in DNA methylation-associated gene expression induced by exposing hFB to Tb-MOF. The images obtained by SEM, confocal microscopy and EDS analysis demonstrated the internalization of Tb-MOF at concentrations as low as $0.05 \mathrm{mg} / \mathrm{mL}$, as well as dose-dependent toxicity in the fibroblasts, with a mean inhibitory concentration (IC50) of 0.260 $\pm 0.012 \mathrm{mg} / \mathrm{mL}$ being observed. Additionally, we detected significant changes in the gene expression levels of DNA methyltransferases and demethylases (important regulators of development of cell) due to the presence of Tb-MOF, suggesting that Tb-MOF could contribute to cell death and destabilize the genome even at low concentrations. These results of this study may establish a foundation for future research attempting to develop and apply secure nanomaterials (e.g., MOFs) to minimize damage to the environment and human health.

\section{Introduction}

Recently, a new class of mesoporous materials, known as metal-organic frameworks (MOFs), has attracted considerable attention. These nanometric materials are composed of organic ligands interspersed with metallic ions or clusters to form networks of nanopores with large surface area and novel properties (Sajid 2016). These characteristics have enabled the materials to be applied with great success in such applications as catalysis, gas storage, energy storage, magnets, drug delivery, optoelectronics, light emitting devices and sensors (Gangu et al. 2016; Zhou et al. 2012). In particular, the design, development, characterization and applications of new nanoscale MOFs have become topics of considerable interest in academic and industrial research (Pal and Bharadwaj 2016; Sajid 2016) because their properties are superior to those of conventional materials. In addition, these materials exhibit characteristics that suggest that they may have applications in biomedicine (Sajid 2016).

For example, nanoscale MOFs composed of lanthanide ions $\left(\mathrm{Ln}^{3+}\right)$ and multitopic organic ligands have attracted the attention of researchers due to their luminescent properties, which are produced by their lanthanide aromatic complexes [Ln(PDA)3] (Lunstroot et al. 2009; Zhao et al. 2009; Zhou et al. 2016). This luminescence has made these MOFs suitable for environmental monitoring (Huang et al. 2019; Liu et al. 2017; Pal and Bharadwaj 2016; Wang et al. 2015) or fluorescence or luminescence bioassays (Dang et al. 2012; Fan et al. 2018). However, despite encouraging results obtained in applying MOFs in such areas as physics, chemistry and biology (Brame et al. 2011; Wuttke et al. 2017), few studies have investigated the toxic effects of these materials on the environment or human health (Sajid 2016). 
In general, it has been reported that the presence of the most common nanomaterials (NMs), such as $\mathrm{TiO}_{2}, \mathrm{SiO}_{2}, \mathrm{CeO}_{2}$, and $\mathrm{Ag}$ nanoparticles, causes adverse effects in vitro on lung, embryonic kidney and liver cells, as well as on skin cells (fibroblasts and keratinocytes) and blood cells, such as macrophages (Franchi et al. 2015; Gong et al. 2010; Sharma et al. 2012; Wang et al. 2009). In these studies, cytotoxic and genotoxic effects were observed, and in the case of $\mathrm{SiO}_{2}$, epigenetic changes on keratinocytes were demonstrated (Gong et al. 2010). In this regard, these cells and others have been employed to test the toxicity generated by NMs according to the primary routes of exposure, such as ingestion, inhalation, blood circulation, and dermal penetration (De Matteis 2017). However, because the skin is a major route of exposure, there is interest in further characterizing the dermal absorption and toxicity produced by NMs, which is usually undertaken using skin cell models, such as keratinocytes and fibroblasts (Wang et al. 2018).

Regarding MOFs, contradictory results have been obtained in several different cell lines regarding the toxicity that these materials induce. Lin et al. (2016) suggest that zinc-based MOFs have potential applications for human healthcare due to their characteristics and because they do not cause significant cytotoxic effects on human cells. In contrast, other studies have shown that MOFs are more toxic than noble metal nanoparticles and cause microbial cell death and damage human cells (Bashir et al. 2015a). Moreover, it has also been observed that the presence of iron-based MOFs in retinal pigmented epithelium human cells damages the plasmatic membrane and depolarizes the mitochondrial membrane due to oxidative stress (Bashir et al. 2015b).

Due to the versatility and composition of MOFs, their exposure to humans is increasing rapidly, which means that studies should be conducted to evaluate the safety of this type of NM if their applications in biomedical, environmental or chemical fields are to be expanded. In particular, it has been suggested that it is important to complement the studies of traditional toxicity pathways with epigenetic studies, since epigenetic changes can be triggered by exposure to NMs (Dusinska et al. 2017). In this regard, NMs can generate oxidative damage to DNA (Simkó et al. 2011), thereby affecting the catalytic capacity of methyltransferases and causing aberrant DNA methylation that can lead to the development of diseases, such as cancer (Dusinska et al. 2017).

DNA methylation, the best-characterized epigenetic modification associated with transcriptional repression (Rinaldi and Benitah 2015), is tightly regulated by sophisticated enzymes that act as writers and erasers on DNA. The first group consists of members of the DNA methyltransferase family, that is, DNMT1, DNMT3a, and DNMT3b, which add a methyl group at the carbon-5 position of cytosine to form 5-methylcytosine ( $5 \mathrm{mC}$ ) (Plongthongkum et al. 2014). In contrast, demethylation is catalyzed by teneleven translocation enzymes (TET1, TET2, and TET3) through $5 \mathrm{mC}$ oxidation to hydroxymethylcytosine, and derivates from this reaction to enable proper gene regulation, cell differentiation, genome integrity, and several biological processes (Rasmussen and Helin 2016). This epigenetic regulation represents a molecular link between environmental factors and the phenotypes that develop; therefore, disturbed epigenetic mechanisms, such as DNA methylation, may lead to the development of complex diseases, such as cancer (Brookes and Shi 2014). Thus, if NMs produce this type of epigenetic change, such as the 
DNA hypomethylation produced by $\mathrm{SiO}_{2}$ on human keratinocyte (Hacat) cells (Gong et al. 2010), these changes could have undesirable effects on human health. Unfortunately, studies on possible epigenetic changes produced by MOF are scarce to date.

Recently, our group successfully synthesized three MOFs with lanthanide complexes, $\left[\mathrm{H}_{2} \mathrm{NMe}_{2}\right]_{3}[\mathrm{Ln}(\mathrm{III})$ (2,6-pyridinedicarboxylate) $\left.{ }_{3}\right](\mathrm{Ln}=\mathrm{Sm}, \mathrm{Eu}, \mathrm{Tb})$, using a solvothermal method in the presence of a base and from inexpensive and readily available reactants, which might be used for diverse environmental and human health applications due to their luminescent properties and high thermal and water stability (Viveros-Andrade et al. 2017). However, the cytotoxic and epigenetic effects of lanthanide MOFs have not been elucidated to date. For this reason, in this work, we evaluated the cytotoxic effects, internalization and changes in DNA methylation-associated gene expression induced by the metal-organic framework [H2NMe2]3 [Tb(PDA)3] "Tb-MOF" on human fibroblast cells ( $\mathrm{hFB}$ ) to provide information relevant to the nanosecurity of Tb-MOF, which is important to minimize damage to the environment and human health.

\section{Materials And Methods \\ 2.1. Materials}

All reagents used for the synthesis of Tb-MOF were purchased from Sigma-Aldrich Chemical Co., and reagent-grade solvents were dried and distilled according to procedures previously established in the literature (Viveros-Andrade et al. 2017). Single crystals were generated using spectroscopy-grade solvents. Melting points were measured in sealed capillaries on an IA-9100 model 10034137/01 Thermo Scientific electrothermal apparatus. Elemental analyses were performed on a PerkinElmer Series II CHNS/O model 2400 analyzer using cystine as a standard. IR spectra in the range of 4000 to $400 \mathrm{~cm}^{-1}$ were recorded in a PerkinElmer FT-IR Spectrum 400 spectrophotometer with a universal ATR sampling accessory at $298 \mathrm{~K}$. The crystal was mounted on glass fiber and studied with an Oxford Diffraction Gemini "A" diffractometer with a CCD area detector, with radiation source of $\lambda_{\text {MoKa }}=0.71073 \AA$ using graphite-monochromatized radiation.

\subsection{General MOF $\left[\mathrm{H}_{2} \mathrm{NMe}_{2}\right]_{3}\left[\mathrm{~Tb}(\mathrm{PDA})_{3}\right]$ synthesis "Tb-MOF"}

The Tb-MOF was synthesized as previously reported (Viveros-Andrade et al. 2017). Briefly, a solution of terbium(III) nitrate pentahydrate $(69.6 \mathrm{mg}, 0.16 \mathrm{mmol})$ in $5 \mathrm{~mL}$ of deionized water was added dropwise to $5 \mathrm{~mL}$ of a methanol solution of 4,4'-bipyridine $(53.5 \mathrm{mg}, 0.32 \mathrm{mmol})$. The reaction mixture was refluxed for 90 min with stirring, after which a solution of pyridine-2,6-dicarboxylate acid $(0.32 \mathrm{mmol})$ in $5 \mathrm{~mL}$ of $N, N^{\prime}$-dimethylformamide (DMF) was slowly added at room temperature (Scheme 1 ). The reaction mixture was transferred into a Teflon-lined stainless-steel vessel. The solution was heated at $120^{\circ} \mathrm{C}$ for 4 days under autogenous pressure; the reaction was slowly cooled to room temperature and subsequently heated at $45^{\circ} \mathrm{C}$ for 2 days; colorless prism-shaped crystals formed from the reaction were filtered off, washed with distilled water, and vacuum-dried. The crystals were insoluble in water and common organic solvents (acetonitrile, methanol, DMF, acetone). Mp $>350^{\circ} \mathrm{C}$. Yield: $60.9 \mathrm{mg}, 72 \%$. IR $\left(\right.$ ATR, $\left.\otimes \mathrm{cm}^{-1}\right): 3543$ 
$(\mathrm{N}-\mathrm{H})$, 1467, $1431(\mathrm{C}=\mathrm{C})_{\text {arom }} 1600(\mathrm{C}=\mathrm{O}), 1572(\mathrm{C}=\mathrm{N}), 1387(\mathrm{C}-\mathrm{O}), 1371(\mathrm{C}-\mathrm{N}), 729(\mathrm{C}-\mathrm{H})_{\text {arom. Anal. }}$ Calc. for $\mathrm{C}_{27} \mathrm{H}_{33} \mathrm{TbN}_{6} \mathrm{O}_{12}$ : $\mathrm{C}, 40.9 ; \mathrm{H}, 4.2 ; \mathrm{N}, 10.6$. Found: $\mathrm{C}, 40.8 ; \mathrm{H}, 4.1 ; \mathrm{N}, 10.5 \%$. The X-ray diffraction of the compound was analyzed by Viveros-Andrade et al. (2017), and the compound had the same molecular structure as that previously reported by Wang et al. (2015) (Supplementary Fig. 1).

\subsection{Cell line and culture}

hFB from healthy breast tissue was provided by the Instituto Tecnológico y de Estudios Superiores de Monterrey, México. These cells were routinely grown in DMEM/F12 without phenol red medium (D2906, Sigma-Aldrich) supplemented with $10 \%$ fetal bovine serum (BIO-S1650, Biowest) and $100 \mu \mathrm{g} / \mathrm{mL}-100$ $\mathrm{U} / \mathrm{mL}-0.25 \mu \mathrm{g} / \mathrm{mL}$ streptomycin, penicillin and amphotericin B (ABL02, Caisson Laboratories), respectively, at $37^{\circ} \mathrm{C}$ in a humidified atmosphere with $5 \% \mathrm{CO}_{2}$. To be analyzed, cells were detached from cell culture flasks with $0.25 \%$ trypsin-EDTA (15090046, Invitrogen). Trypsin was neutralized with the same amount of complete culture medium. Concentration and viable cells were measured by the trypan blue exclusion method with the use of a hemocytometer.

\subsection{Nanomaterial stock solution and dilutions}

A stock solution of Tb-MOF at $3.2 \mathrm{mg} / \mathrm{mL}$ was prepared in Dulbecco's phosphate buffered saline (DPBS 1X, D5652, Sigma-Aldrich). Briefly, the material was pre-sterilized with UV irradiation for 30 min and weighed in a 50-mL sterile tube. Next, the compound was dissolved in sterile DPBS, and the solution was homogenized with a sonicator microtip probe at 130-Watt, 70\% amplitude, for 15 min with a Cole-Parmer 130-Watt Ultrasonic Processor 4347 (UK).

Six concentrations $(0.05,0.1,0.2,0.4,0.8$ and $1.6 \mathrm{mg} / \mathrm{mL})$ were prepared through serial twofold dilution. For this step, the $1.6 \mathrm{mg} / \mathrm{mL}$ dilution was made by adding stock solution into complete $2 X$ DMEM/F12 medium in a 1:1 proportion and then filtered with a $0.2 \mu \mathrm{m}$ syringe filter. The subsequent dilutions were made in $1 \mathrm{X}$ culture medium prepared by dissolving the $2 \mathrm{X}$ medium in DPBS. Stock solution and dilutions were prepared immediately before use.

\subsection{Cytotoxicity assay}

The cell density of hFB exposed and not exposed to Tb-MOF was determined by staining with crystal violet (CV) according to Feoktistova et al. (2016) with some modifications, in which the CV stains proteins and DNA of cells and the intensity of the color is proportional to the number of hypothetically viable adhered cells. Briefly, cells in the exponential phase of growth were inoculated in a flat-bottomed 96-well polystyrene-coated plate at $2 \times 10^{4}$ cells/well in $100 \mu \mathrm{L}$ of complete DMEM/F12 medium and allowed to attach for $24 \mathrm{~h}$. Then, the medium was removed and replaced with $200 \mu \mathrm{L}$ of diluted nanomaterial or only medium in triplicate. As a positive control known to be toxic to the cells, pure DMSO was used. The cells were incubated again for $48 \mathrm{~h}$. After incubation, the cells were washed twice in a gentle stream of tap water, and the plate was inverted and left to dry on filter paper. In each well, $50 \mu \mathrm{L}$ of $0.5 \%$ crystal violet (C6158, Sigma-Aldrich) in methanol (34860, Sigma-Aldrich) was added, and the plate was incubated for $20 \mathrm{~min}$ at room temperature. After being washed four times in a stream of tap water, the plate was air- 
dried, and the remaining stain was dissolved with $200 \mu \mathrm{L}$ of methanol. Absorbance was measured with a microplate reader at $540 \mathrm{~nm}$ (Multiskan FC Thermo Scientific). The percentage of cell density was calculated based on a comparison with control cells as (absorbance of exposed cells/absorbance of control cells) $\times 100$. The cytotoxic concentration $50\left(\mathrm{IC}_{50}\right)$ was calculated by fitting the data to a sigmoidal dose-response equation using GraphPad Prism 7.0. Three independent trials were performed. In addition, photographic records were acquired before staining to observe the morphological changes of the cells and again after staining to demonstrate the effects of Tb-MOF on adhesion, as reflected in cell density.

\subsection{Characterization of effects on human fibroblasts exposed to Tb-MOF}

\subsubsection{Cell preparation for microscopy}

The cells exposed to Tb-MOF were observed by field emission scanning electron microscopy (FESEM JEOL JSM-7600F model) and confocal microscopy to observe the effect and the presence of nanoparticles on or within them. To this end, the cells were grown on Thermanox ${ }^{\mathrm{Tm}}$ coverslips $(13 \mathrm{~mm}$ diameter). Previously, the slides were placed on a sterile Petri dish and exposed to UV irradiation for 30 min. Next, the slides were washed two times with DPBS and decontaminated by being incubated for $24 \mathrm{~h}$ in DPBS with $1 \%$ antibiotic-antimycotic solution. The slides were placed on the wells of 24-well plates and washed twice with DPBS. Cells were inoculated at $5 \times 10^{4}$ cell/well in $1 \mathrm{~mL}$ of culture medium and incubated for $24 \mathrm{~h}$. Next, the culture medium was removed, and dilutions of NMs were added to the wells $(1 \mathrm{~mL})$. The plates were incubated for $48 \mathrm{~h}$, and at the end of that time period, the cells were washed twice with DPBS and examined under a microscope.

\subsubsection{Cell analysis by FESEM}

For the FESEM images, $3 \%$ glutaraldehyde in $0.1 \mathrm{M}$ sodium cacodylate buffer was added to the slides with cells, which were incubated at $4^{\circ} \mathrm{C}$ overnight. After incubation, the slides were washed two times with DPBS, and the samples were dehydrated in increasing concentrations of ethanol (50, 70, 90 and 100\%) for 15 min each time. At the end of dehydration, the samples were placed in a sample holder, which was soaked in ethanol. Next, the sample holder was submitted to a process of critical point drying with liquid $\mathrm{CO}_{2}$ (equipment Quorum K850 model) for $1 \mathrm{~h}$. Later, the samples were fixed on aluminum stubs and were subsequently coated with a layer of gold-palladium (60:40\% each) through a sputtering coater process (equipment Quorum Q150R ES model). Finally, the cells were observed using FESEM. The images were taken by a LABE detector with back-scattered electrons under high vacuum at 10 or $15 \mathrm{kV}$ of voltage with a working distance of approximately $12 \mathrm{~mm}$ and magnifications of 150X and 2000X. Linear energy dispersive spectroscopy (EDS) analysis was performed to identify the presence of nanoparticles in a specific area with an OXFORD-INCA detector.

\subsubsection{Cell imaging by confocal microscopy}


To evaluate the presence of Tb-MOF in the cells, based on its autofluorescence, the hFB cells were grown on Thermanox ${ }^{\mathrm{TM}}$ coverslips and exposed to $0.05,0.2$ and $16 \mathrm{mg} / \mathrm{mL}$ of nanomaterial for $48 \mathrm{~h}$, as previously described. Subsequently, the cells were fixed for $20 \mathrm{~min}$ at room temperature with $4 \%$ paraformaldehyde in DPBS followed by several washes with DPBS, and the fluorescence properties of the cells were observed upon excitation at 330 and $490 \mathrm{~nm}$ accordingly to excitation spectra reported in Viveros-Andrade et al. (2017) by using a confocal laser scanning microscope (Olympus, FV100 SW). The images were acquired and analyzed by using FV10 ASW 3.1 viewer software (Olympus). As a reference, cell samples on slides were counterstained with DAPI mounting medium $\left(\mathrm{H}-1200\right.$, Vectashield $\left.{ }^{\circledR}\right)$ according to the manufacturer's instructions, and the staining signal was detected using an excitation wavelength of $405 \mathrm{~nm}$.

\subsection{RNA isolation and reverse transcriptase-polymerase chain reaction (RT-PCR)}

To analyze the changes in the expression of DNA methyltransferases and demethylases that are encoded by DNMTs (DNMT1, DNMT3a, DNMT3b) and TETs (TET1, TET2 and TET3), respectively, in cells exposed to Tb-MOF, cells were inoculated in a 24-well polystyrene-coated plate at $5 \times 10^{4}$ cells/well in $1 \mathrm{~mL}$ of medium and incubated for $24 \mathrm{~h}$. After incubation, cells were exposed or not (as a control) to three concentrations of Tb-MOF $(0.05,0.2$ and $1.6 \mathrm{mg} / \mathrm{mL})$ and were incubated for $48 \mathrm{~h}$. Thereafter, the cells were washed (twice) with $1 \mathrm{~mL}$ of DPBS $1 \mathrm{X}$ and trypsinized with $0.30 \mathrm{~mL}$ of $0.25 \%$ trypsin-EDTA for 5 min. Subsequently, trypsin was neutralized by the addition of $0.30 \mathrm{~mL}$ of growth medium (DMEM/F12), and the cells were collected in the same conical tube. The tube was centrifuged at $1000 \mathrm{rpm}$ for $5 \mathrm{~min}$, and the pellet was resuspended in $1 \mathrm{~mL}$ of DPBS. The cells were again centrifuged at $12,000 \mathrm{~g}$ for $5 \mathrm{~min}$, and the pellet was employed to extract and purify RNA. Briefly, total RNA was isolated using the Direct-zol RNA miniprep kit (R2051, Zymo Research) according to the manufacturer's protocol. Reverse transcription reactions were performed using one microgram of RNA using the SuperScript III first-strand synthesis system (18080051, Invitrogen) following the manufacturer's instructions. To evaluate the messenger RNA expression of DNA demethylases and methyltransferases, regular PCR was performed with MyTaq ${ }^{\text {TM }}$ DNA Polymerase (21106, Bioline) using the constitutive gene $\beta$-actin as a control. The PCR products were electrophoresed in $1.5 \%$ agarose, stained with ethidium bromide (E1510, Sigma-Aldrich) and photographed using the Gel DocTM XR System (BIO-RAD). The primer sequences employed for the PCR analysis are listed in Supplementary Table S1.

\subsection{Statistical analyses}

$\mathrm{CV}$ tests were performed in three independent trials with at least three replicates per sample, and data were statistically analyzed through parametric one-way ANOVA and Tukey's HSD post hoc test for each mean comparison. Statistical analysis and graphics were analyzed using GraphPad Prism 7.0 software. The data were plotted as the mean \pm standard deviation (SD).

\section{Results}




\subsection{Effects of Tb-MOF on cell density}

To determine the cytotoxic effects of Tb-MOF, hFB cells were exposed or not (for the control) to different concentrations of Tb-MOF for $48 \mathrm{~h}$. After exposure, the effects on cell morphology were visible starting at a concentration of $0.4 \mathrm{mg} / \mathrm{mL}$, from which a percentage of the cells shrank and exhibited a rounded morphology, which was more evident with increased concentrations of Tb-MOF (Fig. 1). In addition, an important reduction in cell density was also observed when the cells were evaluated by CV assay. These results indicate that Tb-MOF induces the loss of adhesion capacity to the substrate and, finally, cell viability (Fig. 1).

Although the effects of Tb-MOF on cell morphology could only be visualized with optical microscopy starting at the concentration of $0.4 \mathrm{mg} / \mathrm{mL}$, the statistical analysis of the data obtained through the $\mathrm{CV}$ assay showed a dose-dependent response, with significant differences $(p<0.05)$ being observed in percentages of cell density with respect to the control at all concentrations (Fig. 2). Thus, the results obtained with these assays suggest that the density of the cells exposed to $0.05 \mathrm{mg} / \mathrm{mL}$ Tb-MOF is different from that of the control and that from the concentration of $0.8 \mathrm{mg} / \mathrm{mL}$ Tb-MOF, the cell density drops to less than $70 \%$ (Fig. 2). Similarly, it was possible to determine the inhibitory concentration $50 \%$ (IC50) by fitting a sigmoidal dose-response curve (Fig. 3). The resulting average was IC50 $=0.260 \pm 0.012$ $\mathrm{mg} / \mathrm{mL}$. Therefore, these results indicated that fibroblast cells are damaged by exposure to Tb-MOF.

\subsection{Cell interaction with Tb-MOF}

To evaluate the cell interaction of Tb-MOF, hFB cells were exposed to the lowest $(0.05 \mathrm{mg} / \mathrm{mL})$ and highest $(1.6 \mathrm{mg} / \mathrm{mL})$ concentrations of Tb-MOF for $48 \mathrm{~h}$ (Fig. 4). In both cases, the presence of Tb-MOF was observed, and the clusters of nanomaterial could be clearly distinguished over cells exposed to 1.6 $\mathrm{mg} / \mathrm{mL}$, where MOF also induced a contraction of the cellular membrane (Fig. 4C). To determine whether the negative effects on cell morphology were due to Tb-MOF internalization within the cells, we carried out FESEM-EDS analysis. This analysis demonstrated the presence of terbium within the cells in the presence of $0.05 \mathrm{mg} / \mathrm{mL}$ Tb-MOF (Fig. 4D). This result shows that cell internalization of Tb-MOF occurs at concentrations as low as $0.05 \mathrm{mg} / \mathrm{mL}$, which could be related to the observed cytotoxicity.

Moreover, considering that Tb-MOF exhibits photoluminescent properties (Viveros-Andrade et al. 2017), cell internalization within hFB of MOF was also evaluated by confocal microscopy. Consistent with the EDS analysis, we noted that Tb-MOF photoluminescent signals were detected in the cell clusters exposed to both 0.05 and $1.6 \mathrm{mg} / \mathrm{mL}$ MOF (Fig. 5) by using a wavelength of 330 and $490 \mathrm{~nm}$. The results showed full nanoparticle internalization within the cells, particularly in the cytoplasmic region and probably in the nucleus, when the cells were exposed to a higher concentration $(1.6 \mathrm{mg} / \mathrm{mL})$ of Tb-MOF (Fig. 5). This result suggests that decreased cell density is correlated with increased internalization of Tb-MOF into fibroblasts.

\subsection{Gene expression patterns of DNA methylation-related genes in hFB cells exposed to Tb-MOF.}


DNA methylation, a well-established epigenetic mark, is widely involved in the control of gene transcription and cellular phenotypic changes, as well as genome stability. Therefore, in this study, we evaluated the gene expression profile of DNMTs (DNMT1, DNMT3a, DNMT3b) and TETs (TET1, TET2 and TET3) on DNA in hFB cells in response to treatment with three different concentrations of Tb-MOF $(0.05$, 0.2 and $1.6 \mathrm{mg} / \mathrm{mL}$ ) after $48 \mathrm{~h}$ of exposure (Fig. 6). We observed that Tb-MOF affected the expression of DNMTs. For instance, the expression of DNMT1 was only slightly affected by all Tb-MOF concentrations, whereas the expression of DNMT3a was downregulated by $0.2 \mathrm{mg} / \mathrm{mL}$. In contrast, the levels of DNMT3B expression were affected by $1.6 \mathrm{mg} / \mathrm{mL}$ but not by 0.05 or $0.2 \mathrm{mg} / \mathrm{mL}$ Tb-MOF. Additionally, because 5$\mathrm{mC}$ can be oxidized to 5 -hydroxymethylcytosine $(5 \mathrm{hmC})$ as part of a pathway to reverse DNA methylation, we further determined the expression profile of the TET genes. Treating hFB with Tb-MOF for $48 \mathrm{~h}$ induced downregulation of TET1 in all treatments, while both TET2 and TET3 expression were affected by 0.2 and $1.6 \mathrm{mg} / \mathrm{mL}$ but not by $0.05 \mathrm{mg} / \mathrm{L}$ of Tb-MOF. Taken together, these results suggest that the decreasing proliferation of hFB could be related to the imbalance of DNA methylation patterns, since the expression levels of both DNMT and TET are affected by Tb-MOF exposure.

\section{Discussion}

In this study, cellular toxicity in hFB was observed after treatment with 0.05 to $1.6 \mathrm{mg} / \mathrm{mL} \mathrm{Tb}-\mathrm{MOF}$, exhibiting a dose-dependent response. Thus, the lowest (12.91\%) and the highest (76.71\%) inhibitions of cell viability were obtained with $0.05 \mathrm{mg} / \mathrm{mL}$ and $1.6 \mathrm{mg} / \mathrm{mL}$, respectively. Similar results have been reported regarding the negative effect exerted on the viability of some human cancerous and healthy cell lines by another type of NMs based on Tb. For instance, in cancer cell lines, a study reported a decrease of approximately $10 \%$ in the viability of HeLa cells exposed to $0.1 \mathrm{mg} / \mathrm{mL} \mathrm{Eu}^{3+}-\mathrm{TbPO}_{4}$ nanoparticles for $72 \mathrm{~h}$ (Di et al. 2011). Similarly, by exposing osteosarcoma cells to $\mathrm{Tb}_{2} \mathrm{O}_{3}(0.001 \mathrm{mg} / \mathrm{mL})$ nanoparticles for 48 h, MG-63 and Saos-2 caused a 50\% reduction in cell viability due to the significant increase in the level of intracellular reactive oxygen species (ROS), which could be related to cytotoxicity (Iram et al. 2016). Similar results were also reported by Setyawati et al. (2013), who observed a viability reduction of $40 \%$ in human skin fibroblasts in the presence of $0.75 \mathrm{mg} / \mathrm{mL} \mathrm{Tb}-\mathrm{Gd}_{2} \mathrm{O}_{3}$ nanoparticles after $24 \mathrm{~h}$ of exposure, suggesting that metal oxide nanoparticles could increase the mechanisms of oxidative stress and induce DNA damage and apoptosis (Setyawati et al., 2013). Our study showed for the first time evidence of the effect of Tb-MOF on hFB, which may indicate that the presence of Tb in the MOF reduced cell viability in hFB due to the increase in the generation of ROS and the induction of DNA damage, as suggested in the reports by Iram et al. (2016) and Setyawati et al. (2013).

On the other hand, in our work, we determined a Tb-MOF IC50 of $0.260 \pm 0.012 \mathrm{mg} / \mathrm{mL}$ (Tb concentration of $0.052 \mathrm{mg} / \mathrm{mL}$ ) on hFB. In this regard, Iram et al. (2016) showed that the presence of $\mathrm{Tb}_{2} \mathrm{O}_{3}$ particles induced an IC50 of $0.001 \mathrm{mg} / \mathrm{mL}$ on the viability of osteosarcoma cells. This value was lower than that obtained in our work, probably due to the Tb concentration in $\mathrm{Tb}_{2} \mathrm{O}_{3}$ particles $(0.0008 \mathrm{mg} / \mathrm{mL})$, which was lower than in our work. However, contrasting results were obtained by Setyawati et al. (2013) regarding the viability of $\mathrm{hFB}$ in the presence of $\mathrm{Tb}-\mathrm{Gd}_{2} \mathrm{O}_{3}$. These researchers observed that $0.75 \mathrm{mg} / \mathrm{mL}$ 
of $\mathrm{Tb}-\mathrm{Gd}_{2} \mathrm{O}_{3}(0.228 \mathrm{mg} \mathrm{Tb} / \mathrm{mL})$ induced a $40 \%$ reduction in the viability of $\mathrm{hFB}$. Thus, the toxic effect obtained at a lower concentration by the Tb may indicate that the specific effects on cell lines could be due to the characteristics of the complexes of NMs and not due to the Tb concentration. Thus, more studies must be conducted to determine the mechanisms by which materials with $\mathrm{Tb}$ as $\mathrm{Tb}-\mathrm{MOF}$ generate cytotoxicity.

On the other hand, through inverted microscopy and FESEM-EDS analysis, it was determined that Tb-MOF $(1.6 \mathrm{mg} / \mathrm{mL})$ induced important changes in fibroblast morphology with respect to the control. For instance, irregular prolongations and oval nuclei, as well as a remarkable contraction of the cells, making them round, decreased their adhesion capacity for the culture surface, which was confirmed when they were lifted when washing the culture plates. Similar results have also been obtained in osteosarcoma cells, dermal fibroblasts and L929 cells when exposed to $\mathrm{Tb}_{2} \mathrm{O}_{3}\left(3.73 \times 10^{-4} \mathrm{mg} / \mathrm{mL}\right), \mathrm{ZnO}(0.5 \mathrm{mg} / \mathrm{mL})$ and Mo $(0.1 \mathrm{mg} / \mathrm{mL})$ nanoparticles, respectively (Iram et al. 2016; Ramasamy et al. 2014; Siddiqui et al. 2015), demonstrating that the morphological changes can also vary depending on the cell line and nanoparticles used (Li et al. 2012). Such losses of the specific morphological characteristics of cells have been demonstrated to be evidence of the induced toxicity of nanoparticles in cells as a stress response (Iram et al. 2016) to the extracellular environment to which they are subjected (Yamaba et al. 2016). Therefore, the subtle effects of Tb-MOF on cell morphology can indirectly lead to disturbance of cell function, while severe morphological alterations, such as rounding and cell contraction, can be interpreted in terms of cell death (Zhivotovsky and Orrenius 2011).

We showed that remarkable changes in cell morphology, such as small protuberances and oval nuclei, in hFB cells were mediated by the internalization of Tb-MOF and by its deposition onto the cell surface (Fig. 4). It is known that nanoparticles can be internalized and form agglomerates (Magdolenova et al. 2012), as well as protuberances, primarily due to the absorption of nanoparticles, which can lead to cell death (Berry et al. 2003; Gupta and Curtis 2004). However, the methods of absorption and biodistribution of nanoparticles depend on the size, shape, and physicochemical and surface properties of nanomaterials (Kunzmann et al. 2011). Once deposited on the cells, these compounds could increase their interaction, thereby facilitating uptake of the particles in this form (Cho et al. 2011) which, in turn, might produce a decrease in cell viability depending on the dose, as well as various metabolic and morphological effects (Plascencia-Villa et al. 2012).

On the other hand, we showed that Tb-MOF induced a change in DNMT expression, mainly affecting $D N M T 3 A$ and $D M T 3 B$, by exposing hFB cells at 0.2 and $1.6 \mathrm{mg} / \mathrm{mL}$, respectively, but without clear evidence of being dose-dependent (Fig. 6). Although there are gaps in the body of knowledge regarding the epigenetic events that happen after cells are exposed to nanomaterials, the induced changes in DNMT expression by Tb-MOF might be related to a reduction in cell proliferation (Fig. 2) and viability (Fig. 1) observed in this work, probably affecting cell cycle-related genes; however, further studies are warranted to elucidate the mechanism by which cytotoxicity occurs on hFB cells. For instance, it may be interesting to determine whether Tb-MOF impairs DNA methyltransferase activity or only leads to repression of DNMT expression. In this regard, it has been reported that exposing keratinocyte cells ( $\mathrm{HaCaT}$ ) to $\mathrm{SiO} 2$ 
nanoparticles leads slight reduction in gene expression of all DNMTs in human embryonic kidney cells (HEK-293) exposed to $\mathrm{ZnO}(0.05 \mathrm{mg} / \mathrm{mL})$ (Choudhury et al. 2017). Moreover, it has been reported that $\mathrm{Ag}$ nanoparticles are able to induce the overexpression of DNMTs in neuronal cells of the mouse (HT22) (Mytych et al. 2017). These results suggest that DNMT expression is dependent on the nanoparticle's specific features and the type of cell to be evaluated.

On the other hand, TET family members (TET1, TET2 and TET3) catalyze the process of demethylation to maintain the correct balance of DNA methylation in the genome (Liu et al. 2013). In this regard, we found that while all Tb-MOF concentrations decreased TET1 and TET3 expression, Tb-MOF induced an increase in TET2 expression (Fig. 6).

Although the expression levels of TETs can vary among cells/organs, their specific activities in many biological processes have not been elucidated (Delatte and Fuks 2013; Jiang et al. 2017). For example, it has been reported that point mutations of TET1, TET2, and TET3 lead to the development of prostate, skin, breast and colon cancer (Choudhury et al. 2017; Rasmussen and Helin 2016). These results suggest that TET proteins have tumor-suppressor functions that are essential for maintaining genome integrity. Therefore, the dysregulation of TET proteins could compromise human health.

Our results suggest that cells exposed to Tb-MOF may exhibit cytotoxic effects by changing the epigenetic landscape (in vitro and in vivo) with a significant impact on cell behavior, which could lead to the development of human diseases; however, there is little information regarding the mechanism that leads to the downregulation of TET expression by such compounds, indicating that further studies are warranted to clarify in greater depth the possible mechanisms governing the effects that nanomaterials, such as Tb-MOF, have on human health.

\section{Conclusion}

Taken together, our results clearly show that Tb-MOF can be absorbed and internalized in hFB cells, disrupting the morphology, adhesion properties, viability and cytotoxicity induction of the cells, probably by affecting DNA methylation-based processes by interfering with the catalytic domains of DNMT and TET family proteins. In addition, the responses obtained in the hFB suggest that Tb-MOF may activate ROS generation. Clearly, more studies are needed to determine the functional consequences and potential effects on human health caused by exposure to Tb-MOF and/or nanomaterial complexes. This study presents evidence relevant to the possible damage caused by some nanomaterials, such as MOFs, when they are used without knowledge of their effects on the environment and human health.

\section{Declarations}

\section{Ethics approval and consent to participate}

Not applicable 


\section{Consent for publication}

Not applicable

\section{Availability of data and materials}

Not applicable

\section{Competing interests}

The authors declare there are no competing financial interests.

\section{Funding}

This work was supported by funds of the Consul National of Science and Technology (CONACYT) (Grant No. 284140).

\section{Authors' contributions}

Carrillo-Cocom Leydi Maribel, Juárez-Méndez Lucia and Nic-Can, Geovanny Ignacio, carried out the experiment. Carrillo-Cocom Leydi Maribel and Nic-Can, Geovanny Ignacio wrote the manuscript with support from Rincón Susana, Rivera-Villanueva José María and Zepeda Alejandro. Zepeda Alejandro conceived the original idea and supervised the project.

\section{References}

1. Bashir S, Luo Z, Martinez B, Okakpu U, Liu J (2015a) Biosafety Evaluation of Nanoscaled Porous Energy Materials, Nanomaterials for Sustainable Energy. Oxford University Press, Washington, DC, pp. 239-268. doi: 10.1021/bk-2015-1213.ch010

2. Bashir S, Wang T, Chen Y.P, Liu JL (2015b) Nanomaterials Induced Cell Damage, in: Hepel, M., Andreescu, S. (Eds.), Oxidative Stress: Diagnostics, prevention, and therapy. Oxford University Press, Washington, DC, pp. 431-461. doi: 10.1021/bk-2015-1200.ch019

3. Berry C, Wells S, Charles S, Curtis AS (2003) Dextran and albumin derivatised iron oxide nanoparticles: influence on fibroblasts in vitro. Biomaterials. 24:4551-7. doi: 10.1016/S01429612(03)00237-0

4. Brame J, Li Q, Alvarez PJ (2011) Nanotechnology-enabled water treatment and reuse: emerging opportunities and challenges for developing countries. Trends Food Sci Technol. 22:618-24. doi: 10.1016/j.tifs.2011.01.004 
5. Brookes E, Shi Y (2014) Diverse epigenetic mechanisms of human disease. Annu Rev Genet. 48:23768. doi: 10.1146/annurev-genet-120213-092518

6. Cho EC, Zhang Q, Xia Y (2011) The effect of sedimentation and diffusion on cellular uptake of gold nanoparticles. Nat Nanotechnol. 6: 385-91. doi: 10.1038/nnano.2011.58

7. Choudhury SR, Ordaz J, Lo CL, Damayanti NP, Zhou F, Irudayaraj J (2017) From the Cover: Zinc oxide Nanoparticles-Induced Reactive Oxygen Species Promotes Multimodal Cyto- and Epigenetic Toxicity. Toxicol Sci. 156:261-74. doi: 10.1093/toxsci/kfw252

8. Dang S, Ma E, Sun ZM, Zhang H (2012) A layer-structured Eu-MOF as a highly selective fluorescent probe for Fe3+ detection through a cation-exchange approach. J Mater. Chem. 33:16920-6. doi: 10.1039/C2JM32661B

9. De Matteis V (2017) Exposure to Inorganic Nanoparticles: Routes of Entry, Immune Response, Biodistribution and In Vitro/In Vivo Toxicity Evaluation. Toxics. 5:29. doi: 10.3390/toxics5040029

10. Delatte B, Fuks, F (2013) TET proteins: on the frenetic hunt for new cytosine modifications. Brief Funct Genomics. 12:191-204. doi: 10.1093/bfgp/elt010

11. Di W, Li J, Shirahata N, Sakka Y, Willinger MG, Pinna N (2011) Photoluminescence, cytotoxicity and in vitro imaging of hexagonal terbium phosphate nanoparticles doped with europium. Nanoscale. 3 : 1263-9. doi: 10.1039/c0nr00673d

12. Dusinska M, Tulinska J, El Yamani N, Kuricova M, Liskova A, Rollerova E, Runden-Pran E, Smolkova B (2017) Immunotoxicity, genotoxicity and epigenetic toxicity of nanomaterials: New strategies for toxicity testing? Food Chem Toxicol. 109: 797-811. doi: 10.1016/j.fct.2017.08.030

13. Fan T, Xia T, Zhang Q, Cui Y, Yang Y, Qian G (2018) A porous and luminescent metal-organic framework containing triazine group for sensing and imaging of Zn2+. Micropor Mesopor Mat. 266:1-6. doi: 10.1016/j.micromeso.2018.02.050

14. Franchi LP, Manshian BB, de Souza TA, Soenen SJ, Matsubara EY, Rosolen JM, Takahashi CS (2015) Cyto- and genotoxic effects of metallic nanoparticles in untransformed human fibroblast. Toxicol In Vitro. 29:1319-1331. doi: 10.1016/j.tiv.2015.05.010

15. Gangu KK, Maddila S, Mukkamala SB, Jonnalgadda SB (2016) A review on contemporary MetalOrganic Framework materials. Inorganica Chim Acta. 446:61-74. doi: 10.1016/j.ica.2016.02.062

16. Gong C, Tao G, Yang L, Liu J, Liu Q, Zhuang Z (2010) SiO(2) nanoparticles induce global genomic hypomethylation in HaCaT cells. Biochem Biophys Res Commun. 397:397-400. doi: 10.1016/j.bbrc.2010.05.076

17. Gupta AK, Curtis AS (2004) Lactoferrin and ceruloplasmin derivatized superparamagnetic iron oxide nanoparticles for targeting cell surface receptors. Biomaterials. 25, 3029-3040. doi: 10.1016/j.biomaterials.2003.09.095

18. Huang WH, Ren J, Yang YH, Li XM, Wang Q, Jiang N, Yu JQ, Wang F, Zhang J. (2019) Water-Stable Metal-Organic Frameworks with Selective Sensing on $\mathrm{Fe}(3+)$ and Nitroaromatic Explosives, and Stimuli-Responsive Luminescence on Lanthanide Encapsulation. Inorg Chem. 58:1481-91. doi: 10.1021/acs.inorgchem.8b02994 
19. Iram S, Khan S, Ansary AA, Arshad M, Siddiqui S, Ahmad E, Khan RH, Khan MS (2016) Biogenic terbium oxide nanoparticles as the vanguard against osteosarcoma. Spectrochim Acta A Mol Biomol Spectrosc. 168:123-131. doi: 10.1016/j.saa.2016.05.053

20. Jiang D, Wei S, Chen F, Zhang Y, Li J (2017) TET3-mediated DNA oxidation promotes ATR-dependent DNA damage response. EMBO Rep. 18:781-796. doi: 10.15252/embr.201643179

21. Kunzmann A, Andersson B, Thurnherr T, Krug H, Scheynius A, Fadeel B (2011) Toxicology of engineered nanomaterials: focus on biocompatibility, biodistribution and biodegradation. Biochim Biophys Acta. 1810:361-373. doi:10.1016/j.bbagen.2010.04.007

22. Li L, Mak KY, Shi J, Koon HK, Leung CH, Wong CM, Leung CW, Mak CS, Chan NM, Zhong W, Lin KW, Wu EX, Pong PW (2012) Comparative in vitro cytotoxicity study on uncoated magnetic nanoparticles: effects on cell viability, cell morphology, and cellular uptake. J Nanosci Nanotechnol. 12:9010-7. doi: 10.1166/jnn.2012.6755

23. Lin W, Hu Q, Yu J, Jiang K, Yang Y, Xiang S, Cui Y, Yang Y, Wang Z, Qian G (2016) Low Cytotoxic Metal-Organic Frameworks as Temperature-Responsive Drug Carriers. Chempluschem. 81: 804-810. doi: 10.1002/cplu.201600142

24. Liu R, Jin Y, Tang WH, Qin L, Zhang X, Tellides G, Hwa J, Yu J, Martin KA (2013) Ten-eleven translocation-2 (TET2) is a master regulator of smooth muscle cell plasticity. Circulation. 128:20472057. doi: 10.1161/CIRCULATIONAHA.113.002887

25. Liu W, Dai X, Bai Z, Wang Y, Yang Z, Zhang L, Xu L, Chen L, Li Y, Gui D, Diwu J, Wang J, Zhou R, Chai Z, Wang S (2017) Highly Sensitive and Selective Uranium Detection in Natural Water Systems Using a Luminescent Mesoporous Metal-Organic Framework Equipped with Abundant Lewis Basic Sites: A Combined Batch, X-ray Absorption Spectroscopy, and First Principles Simulation Investigation. Environ Sci Technol. 51:3911-3921. doi: 10.1021/acs.est.6b06305

26. Lunstroot K, Nockemann P, Van Hecke K, Van Meervelt L, Gorller-Walrand C, Binnemans K, Driesen K (2009) Visible and near-infrared emission by samarium(III)-containing ionic liquid mixtures. Inorg Chem. 48:3018-3026. doi: 10.1021/ic8020782

27. Magdolenova Z, Bilanicova D, Pojana G, Fjellsbo LM, Hudecova A, Hasplova K, Marcomini A, Dusinska M (2012) Impact of agglomeration and different dispersions of titanium dioxide nanoparticles on the human related in vitro cytotoxicity and genotoxicity. J Environ Monit. 14: 455464. doi: 10.1039/c2em10746e

28. Mytych J, Zebrowski J, Lewinska A, Wnuk M (2017) Prolonged Effects of Silver Nanoparticles on p53/p21 Pathway-Mediated Proliferation, DNA Damage Response, and Methylation Parameters in HT22 Hippocampal Neuronal Cells. Mol Neurobiol. 54:1285-1300. doi: 10.1007/s12035-016-9688-6

29. Pal S, Bharadwaj PK (2016) A Luminescent Terbium MOF Containing Hydroxyl Groups Exhibits Selective Sensing of Nitroaromatic Compounds and Fe(III) lons. Cryst Growth Des. 16:5852-5858. doi: 10.1021/acs.cgd.6b00930

30. Plascencia-Villa G, Starr CR, Armstrong LS, Ponce A, Jose-Yacaman M (2012) Imaging interactions of metal oxide nanoparticles with macrophage cells by ultra-high resolution scanning electron 
microscopy techniques. Integr Biol (Camb). 4: 1358-1366. doi: 10.1039/c2ib20172k

31. Plongthongkum N, Diep DH, Zhang K (2014) Advances in the profiling of DNA modifications: cytosine methylation and beyond. Nat Rev Genet. 15:647-661. doi: 10.1038/nrg3772

32. Ramasamy M, Das M, An SS, Yi DK (2014) Role of surface modification in zinc oxide nanoparticles and its toxicity assessment toward human dermal fibroblast cells. Int J Nanomedicine. 9:3707-3718. doi: $10.2147 /$ IJN.S65086

33. Rasmussen KD, Helin K (2016) Role of TET enzymes in DNA methylation, development, and cancer. Genes Dev. 30:733-750. doi: 10.1101/gad.276568.115

34. Rinaldi L, Benitah SA (2015) Epigenetic regulation of adult stem cell function. FEBS J. 282:15891604. doi: $10.1111 /$ febs. 12946

35. Sajid M. Toxicity of nanoscale metal organic frameworks: a perspective (2016) Environ Sci Pollut Res Int. 23:14805-7. doi: 10.1007/s11356-016-7053-y

36. Setyawati MI, Khoo PK, Eng BH, Xiong S, Zhao X, Das GK, Tan TT, Loo JS, Leong DT, Ng KW (2013) Cytotoxic and genotoxic characterization of titanium dioxide, gadolinium oxide, and poly(lactic-coglycolic acid) nanoparticles in human fibroblasts. J Biomed Mater Res. A 101:633-640. doi:

10.1002/jbm.a.34363

37. Sharma V, Anderson D, Dhawan A (2012) Zinc oxide nanoparticles induce oxidative DNA damage and ROS-triggered mitochondria mediated apoptosis in human liver cells (HepG2). Apoptosis. 17:852-870. doi: 10.1007/s10495-012-0705-6

38. Shimada H, Nagano M, Funakoshi T, Kojima S (1996) Pulmonary toxicity of systemic terbium chloride in mice. J Toxicol Environ Health. 48:81-92. doi: 10.1080/009841096161483

39. Siddiqui MA, Saquib Q, Ahamed M, Farshori NN, Ahmad J, Wahab R, Khan ST, Alhadlaq HA, Musarrat J, Al-Khedhairy AA. Pant AB (2015) Molybdenum nanoparticles-induced cytotoxicity, oxidative stress, G2/M arrest, and DNA damage in mouse skin fibroblast cells (L929). Colloids Surf B Biointerfaces 125, 73-81. doi: 10.1016/j.colsurfb.2014.11.014

40. Simkó M, Gazsó A, Fiedeler U, Nentwich M (2011) Nanoparticles, free radicals and oxidative stress. Nano Trust-Dossier. 12:1-3.

41. Viveros-Andrade AG, Colorado-Peralta R, Flores-Alamo M, Castillo-Blum SE, Durán-Hernández J, Rivera JM (2017) Solvothermal synthesis and spectroscopic characterization of three lanthanide complexes with high luminescent properties [H 2 NMe 2 ] 3 [ $\mathrm{Ln}(\mathrm{IIII})(2,6$-pyridinedicarboxylate) 3 ] $(\mathrm{Ln}=$ Sm, Eu, Tb): In the presence of 4,4'-Bipyridyl. J Mol Struct. 1145:10-17. doi:

10.1016/j.molstruc.2017.05.055

42. Wang F, Gao F, Lan M, Yuan H, Huang Y, Liu J (2009) Oxidative stress contributes to silica nanoparticle-induced cytotoxicity in human embryonic kidney cells. Toxicol In Vitro. 23:808-815. doi: 10.1016/j.tiv.2009.04.009

43. Wang J, Sun W, Chang S, Liu H, Zhang G, Wang Y, Liu Z (2015) A terbium metal-organic framework with stable luminescent emission in a wide $\mathrm{pH}$ range that acts as a quantitative detection material for nitroaromatics. RSC Advances. 5:48574-48579. doi: 10.1039/c5ra06308f 
44. Wang M, Lai X, Shao L, Li L (2018) Evaluation of immunoresponses and cytotoxicity from skin exposure to metallic nanoparticles. Int J Nanomedicine. 13:4445-4459. doi: 10.2147/IJN.S170745

45. Wuttke S, Zimpel A, Bein T, Braig S, Stoiber K, Vollmar A, Muller D, Haastert-Talini K, Schaeske J, Stiesch M, Zahn G, Mohmeyer A, Behrens P, Eickelberg O, Bolukbas DA, Meiners S (2017) Validating Metal-Organic Framework Nanoparticles for Their Nanosafety in Diverse Biomedical Applications. Adv Healthc Mater. 6:2. doi: 10.1002/adhm.201600818

46. Yamaba H, Haba M, Kunita M, Sakaida T, Tanaka H, Yashiro Y, Nakata S (2016) Morphological change of skin fibroblasts induced by UV Irradiation is involved in photoaging. Exp Dermatol. 25 Suppl 3:45-51. doi: 10.1111/exd.13084

47. Yang Q, Wang L, Zhou Q, Huang X (2015) Toxic effects of heavy metal terbium ion on the composition and functions of cell membrane in horseradish roots. Ecotoxicol Environ Saf. 111:4858. doi: 10.1016/j.ecoenv.2014.10.002

48. Zhao B, Chen XY, Chen Z, Shi W, Cheng P, Yan SP, Liao DZ (2009) A porous 3D heterometal-organic framework containing both lanthanide and high-spin Fe(ii) ions. Chem Commun (Camb). 3113-5. doi $10.1039 / \mathrm{b} 821496 \mathrm{~d}$

49. Zhivotovsky B, Orrenius S (2011) Calcium and cell death mechanisms: a perspective from the cell death community. Cell Calcium. 50:211-221. doi: 10.1016/j.ceca.2011.03.003

50. Zhou HC, Long JR, Yaghi OM (2012) Introduction to metal-organic frameworks. Chem Rev. 112:673674. doi: $10.1021 / \operatorname{cr} 300014 x$

51. Zhou ZY, Han YH, Xing XS, Du SW (2016) Microporous Lanthanide Metal-Organic Frameworks with Multiple 1D Channels: Tunable Colors, White-Light Emission, and Luminescent Sensing for Iron(II) and Iron(III). Chempluschem. 81:798-803. doi: 10.1002/cplu.201600141

\section{Figures}



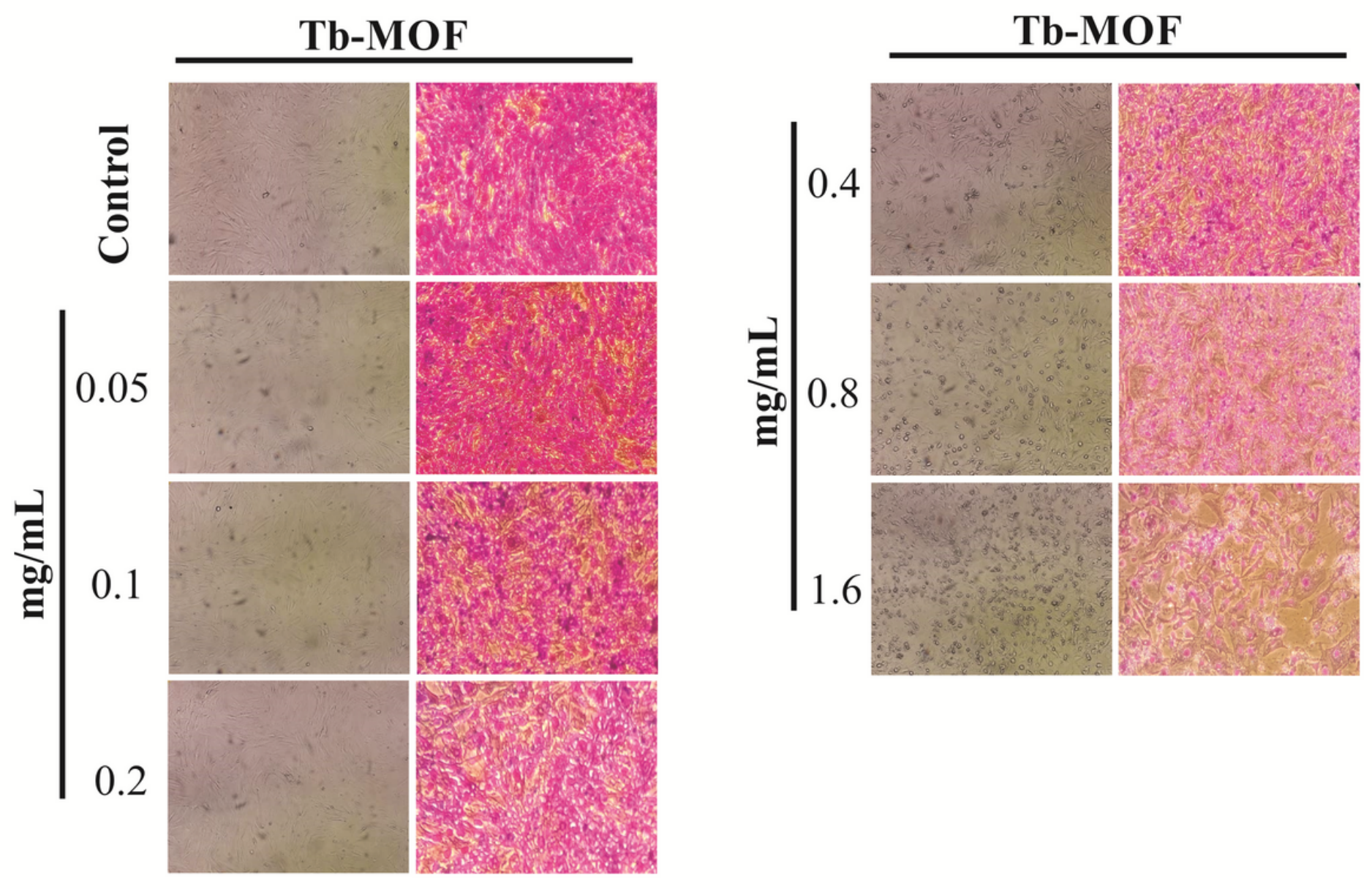

Figure 1

Morphology of human fibroblasts exposed to several concentrations of Tb-MOF. after $48 \mathrm{~h}$ of exposure. Magnification 20X 


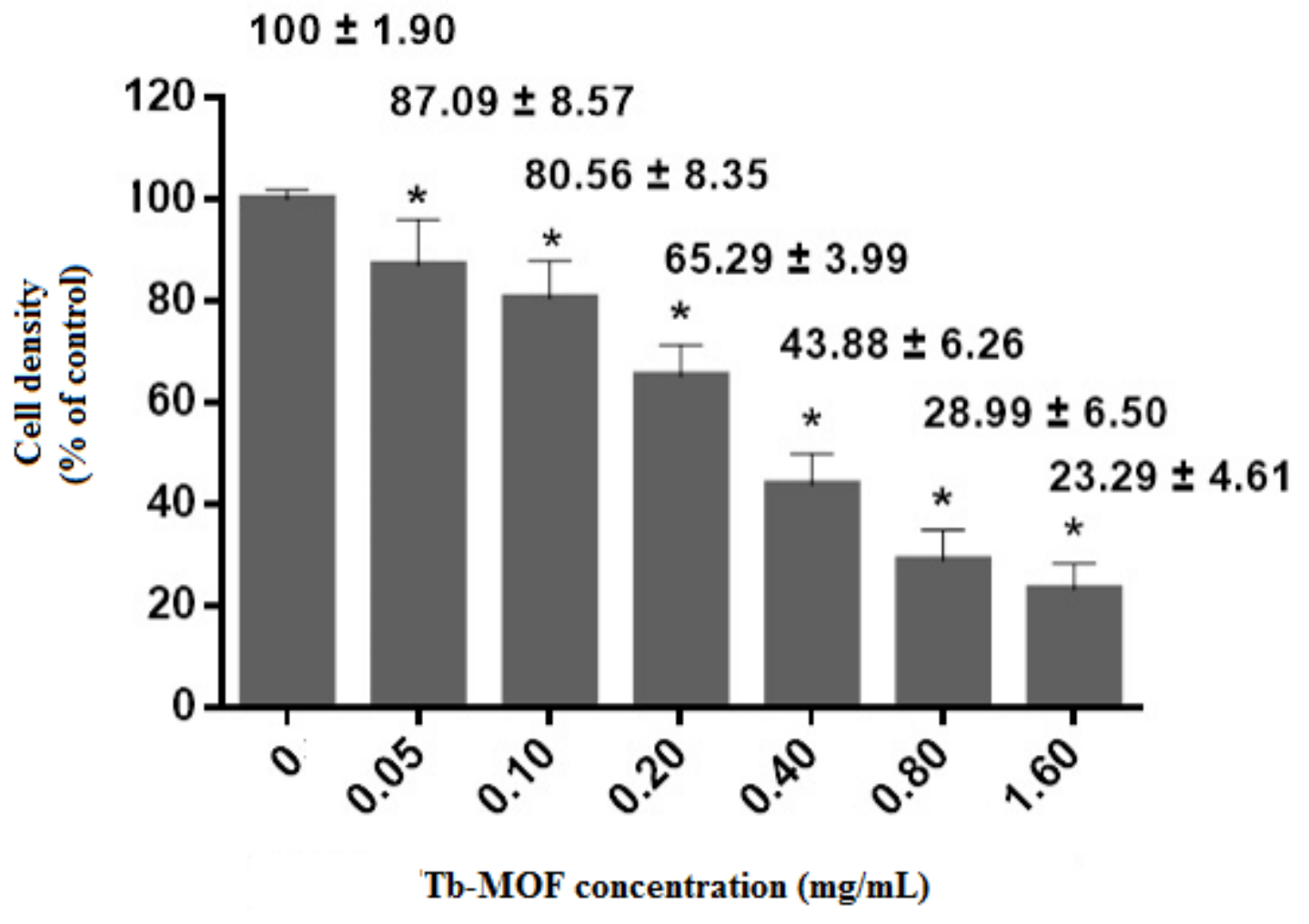

Figure 2

Cell density of human fibroblasts cells exposed to Tb-MOF. The cell density was calculated with respect to the density of the control (cells incubated without nanomaterials). The error bars indicate the standard deviation $(n=3)$. * Indicates significant differences $(p<0.05)$ calculated by Tukey's HSD post-hoc test

A

B
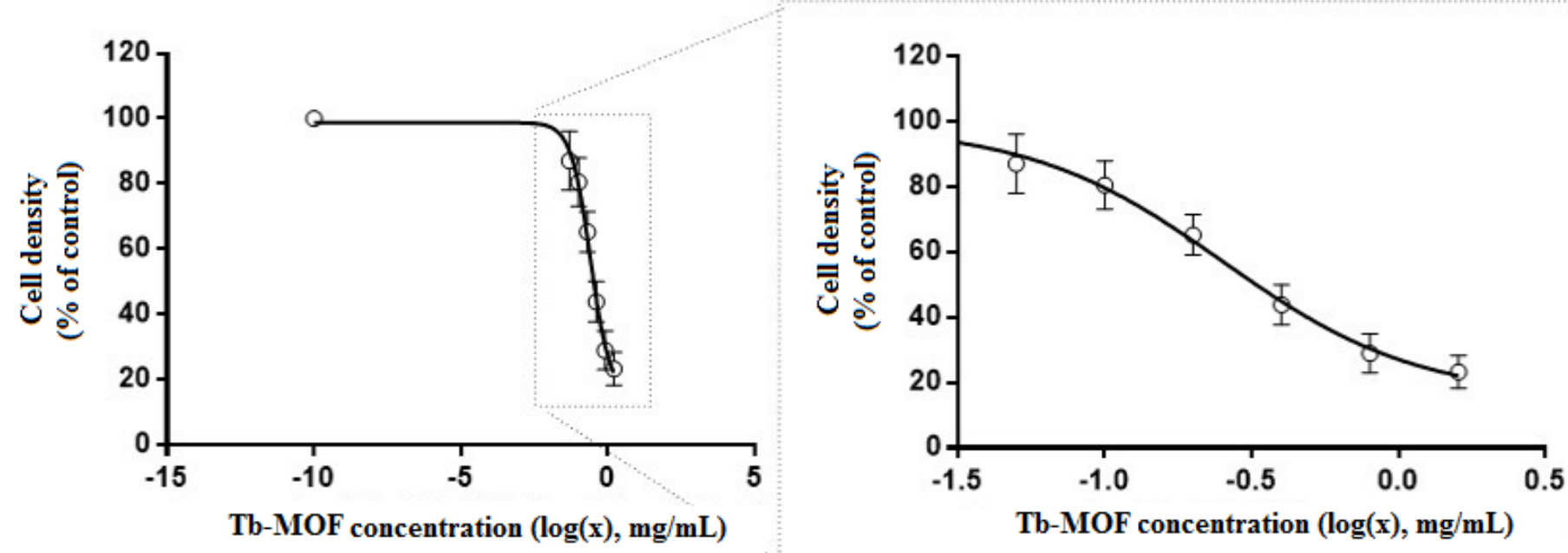

Figure 3 
Sigmoidal dose-response curve for Tb-MOF. Determinations of the relative cell density of human fibroblasts were carried out in three independent experiments. The values are expressed as the mean \pm standard deviation. The concentrations of Tb-MOF used were 1.6, 0.8, 0.4, 0.2, $0.1,0.05$ and 0 (control) $\mathrm{mg} / \mathrm{mL}$. A) shows all concentrations and B) shows adjustment between 0.05 and $1.6 \mathrm{mg} / \mathrm{mL}$, where the curve presents a correlation between the relative cell density and the applied dose of MOF $(R 2=0.974)$
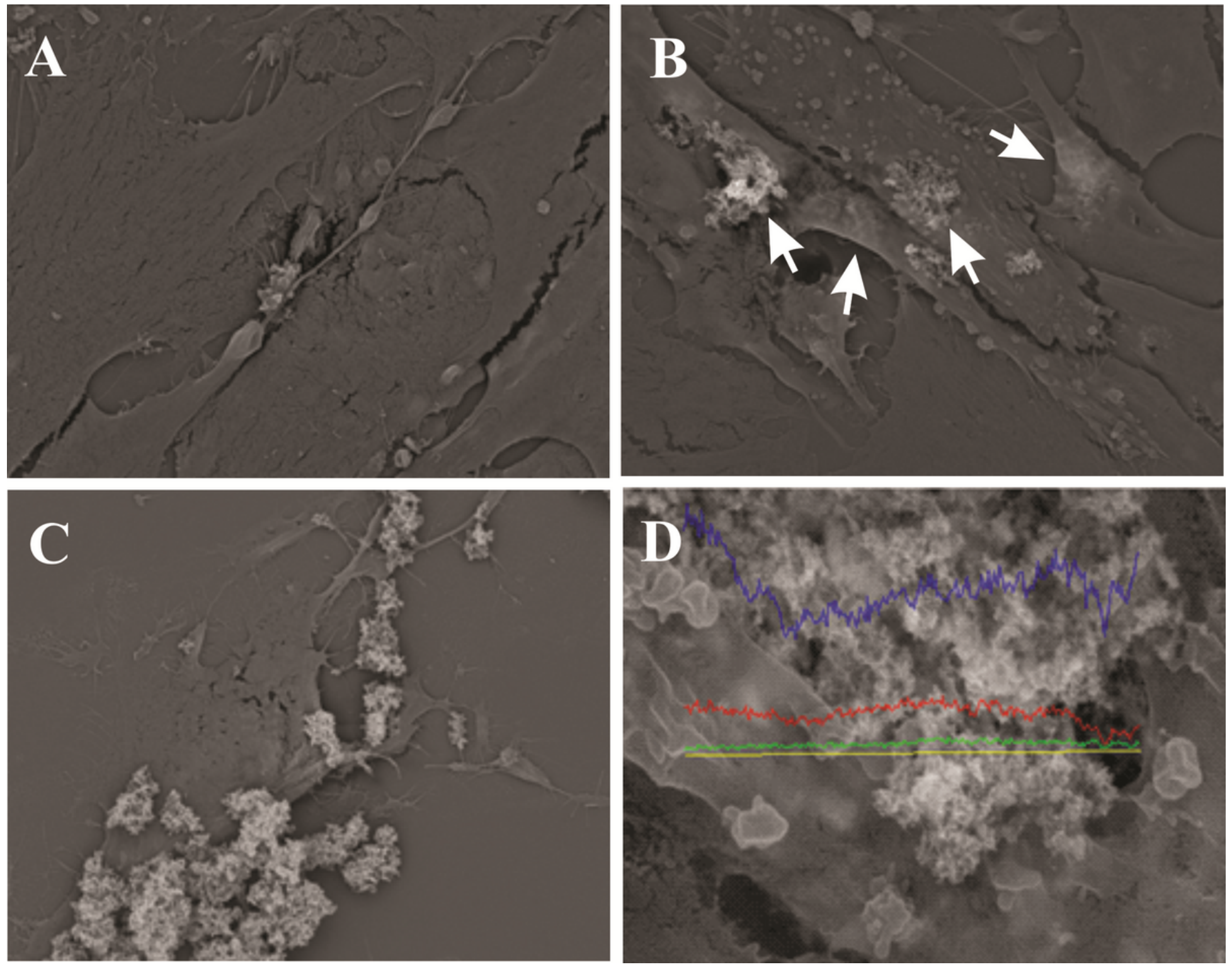

\section{Figure 4}

Representative FESEM images of human fibroblasts cells exposed to Tb-MOF. A) untreated cell (control), B) cell with $0.05 \mathrm{mg} / \mathrm{mL}$ of nanomaterial that was deposited or internalized in the cell (white arrows), C) cell treated with $1.6 \mathrm{mg} / \mathrm{mL}$ of MOF which was deposited on its surface, D) linear energy dispersive spectroscopy analysis of cells treated with $0.05 \mathrm{mg} / \mathrm{mL}$ of nanomaterial, lines represent - Carbon, -Oxygen, -- Terbium and - section analyzed 

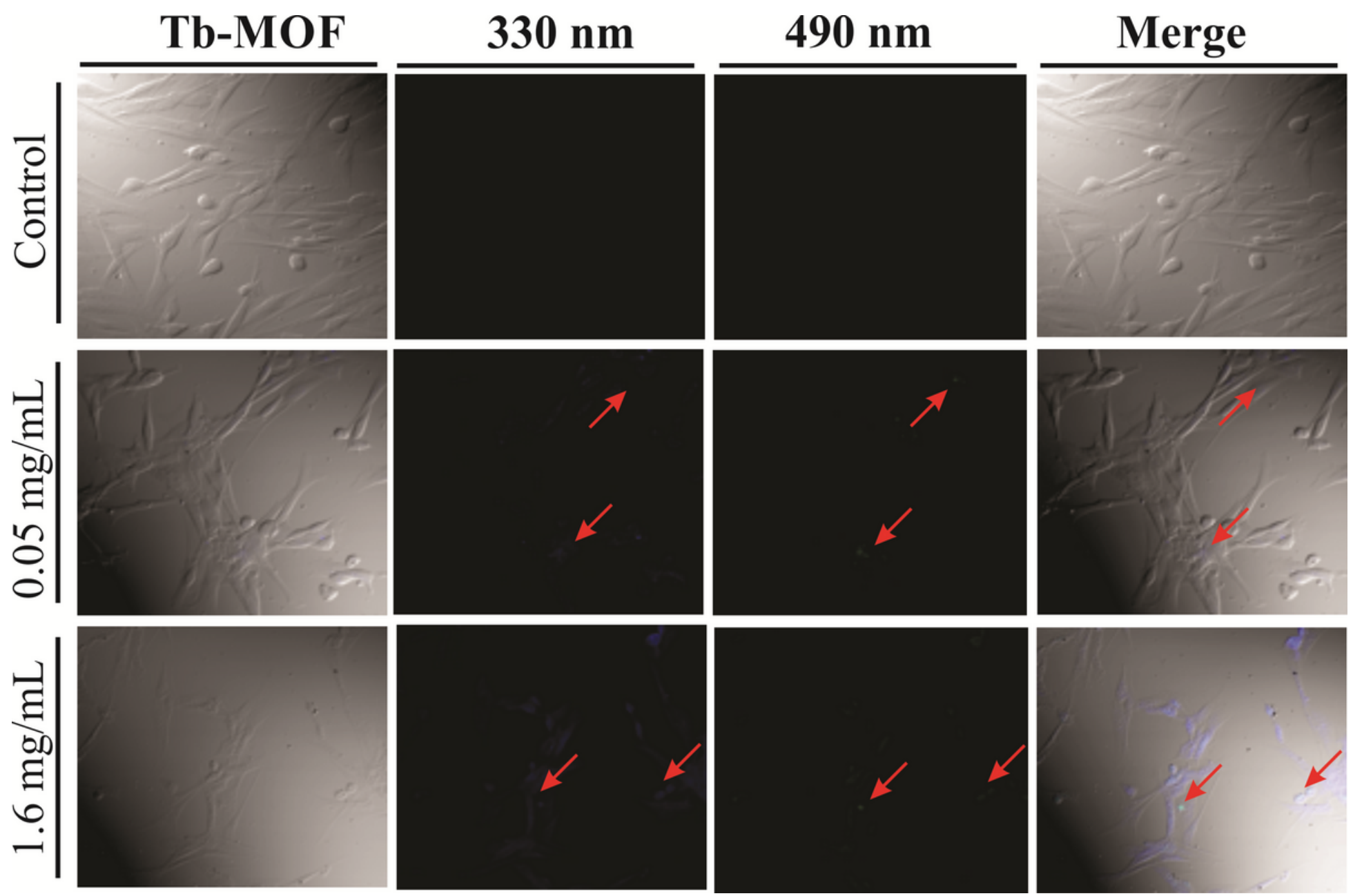

Figure 5

Photoluminescent properties of Tb-MOF in human fibroblast cells. Confocal microscopy analysis of human fibroblast cells exposed or not (control) at two concentration of Tb-MOF to determine its internalization into fibroblasts. Photoluminescent properties of Tb-MOF were detected by using excitation wavelength of 330nm and $490 \mathrm{~nm}$. Red arrows indicate the presence of Tb-MOF in either cytoplasm or nucleus 


\section{Tb-MOF $(\mathrm{mg} / \mathrm{mL})$ \\ Ctrl $\quad 0.05 \quad 0.2 \quad 1.6$}

DNMT1

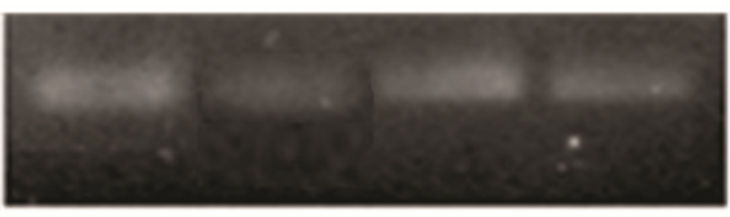

DNMT3A

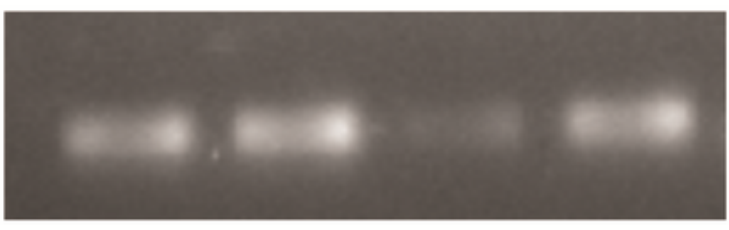

DNMT3B

TET1

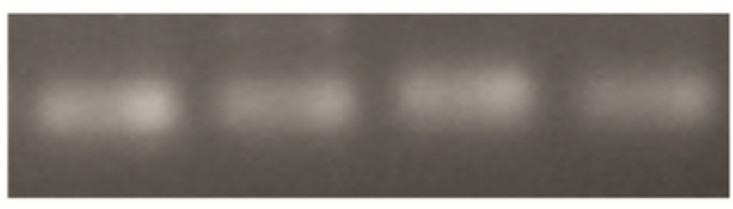

TET2
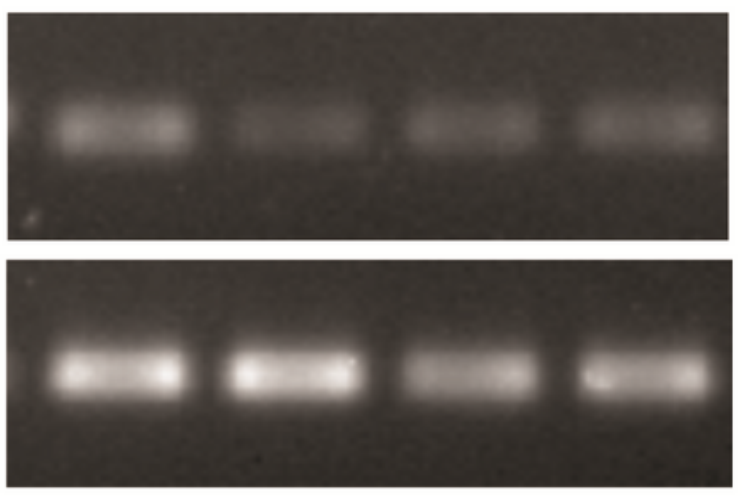

TET3

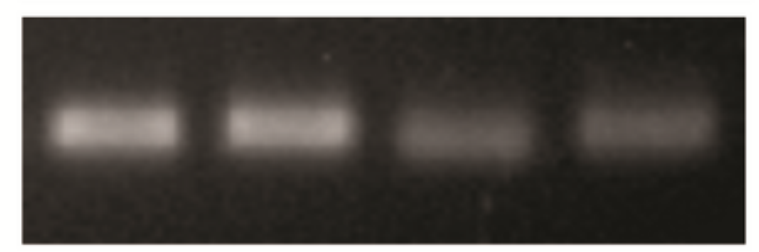

\section{$\beta-A C T I N E$}

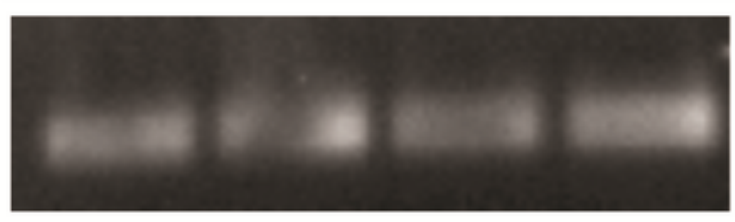

\section{Figure 6}

Gene expression pattern of DNA methyltransferases and demethylases in hFB cell induced by Tb-MOF. RT-PCR analysis of DNA methyltransferases (DNMT1, DNMT3a, DNMT3b) and Ten eleven translocation family members (TET1, TET2, TET3) during the treatment of human fibroblast cells with different concentrations of Tb-MOF for $48 \mathrm{~h}$. Total RNA was used for RT-PCR analysis. -ACTIN was used as a reference gene 

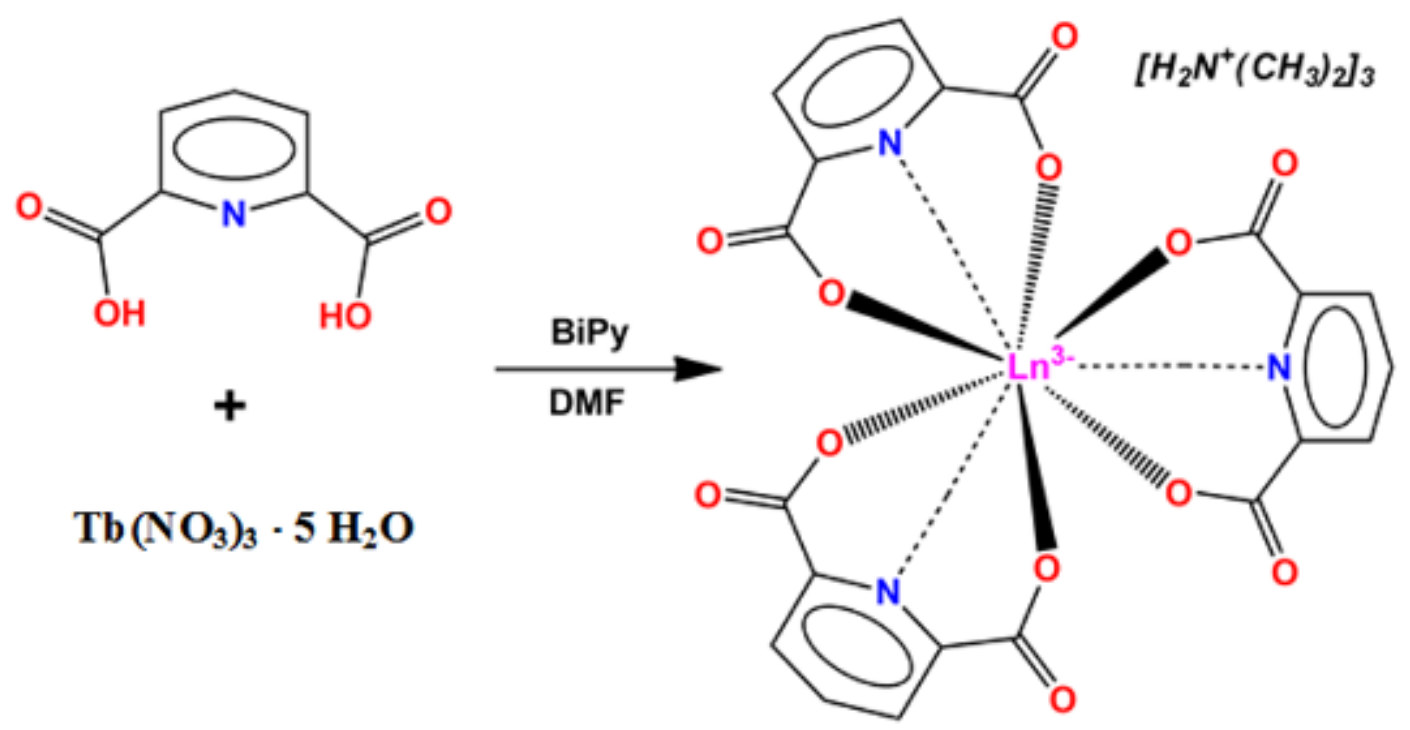

Figure 7

$\mathrm{Tb}\left(\mathrm{NO}_{3}\right)_{3} \cdot 5 \mathrm{H}_{2} \mathrm{O}$

Reaction of ligand H2PDA with Terbium nitrate

\section{Supplementary Files}

This is a list of supplementary files associated with this preprint. Click to download.

- FigS1.tiff

- TablesS1.docx 